\title{
Construct Validation of Consumer Complaint Behavioral Scale in the Malaysian Mobile Phone Services Industry
}

\author{
Mohd. Khirzan Badzli A Rahman ${ }^{1}$, Sharifah Azizah Haron², Laily Hj. Paim², Mumtazah Othman², Syuhaily \\ Osman $^{2} \&$ Abdul Kadir Othman ${ }^{1}$ \\ ${ }^{1}$ Faculty of Business Management, Universiti Teknologi MARA, Shah Alam, Selangor, Malaysia \\ ${ }^{2}$ Faculty of Human Ecology, Universiti Putra Malaysia, Serdang, Malaysia \\ Correspondence: Abdul Kadir Othman, Faculty of Business Management, Universiti Teknologi MARA, 40450 \\ Shah Alam, Selangor, Malaysia. Tel: 60-13-982-3953. E-mail: abdkadir@salam.uitm.edu.my
}

Received: January 24, 2014 Accepted: March 6, 2014 Online Published: August 18, 2015

doi:10.5539/ass.v11n24p6 URL: http://dx.doi.org/10.5539/ass.v11n24p6

\begin{abstract}
Consumer Complaint Behavior (CCB) is a topic that is continuously being studied globally at various types of industries and from different perspectives. Nevertheless, $\mathrm{CCB}$ has varying definitions and different conceptualizations used among the researchers. Public Action, Private Action, No Action and Voice are among the underlying constructs that are frequently used by the researchers to represent CCB. This paper attempts to further clarify the possible and valid constructs of CCB based on the result of EFA and CFA for complainers and non-complainers. SPSS version 21 and AMOS version 21 were used to analyze the data and the results of Goodness of Fit, Average Variance Extracted have met the suggested threshold values. The study also revealed the existence of four factors of CCB for complainers and two factors for non-complainers.
\end{abstract}

Keywords: consumer complaint behavior, public action, private action

\section{Introduction}

The telecommunication industry is one of the major contributors to the Malaysian economy. The revenue from the communications sector in Malaysia has increased by $11 \%$ to RM45.8 billion compared to RM41.2 billion in 2009. The performance of this industry compared to five years ago has grown at a compounded annual growth rate or CAGR of $46 \%$, an increase of RM14.4 billion. In 2010 also, the domestic revenue for the communications and multimedia is at RM35.4 billion, representing 6.3\% of Gross Domestic Product (GDP) (Malaysian Communication and Multimedia Commission, Annual Report, 2010). It shows that the telecommunication industry has made a significant contribution to the economic growth. Hence, many countries give more focus to improve its telecommunication technology. Owing to the availability of telecommunication technology, mobile phone becomes increasingly important in daily life. People are more relying on mobile phone than ever before and people in their daily life use mobile phones absolutely far beyond other consumer products (Yang \& Lay, 2011). The consensus agreement that mobile phone is not only as tools for communication, but also as tools for people working and emotional interaction has made this device becomes one of mandatory items to have. The mobile phone is viewed as an important communication tool and has become an integral part of the society. Malaysians are increasingly using the mobile phone rather than the fixed line telephone as a way to keep in touch with their family, friends, colleagues and business associates (Zulkefly \& Baharudin, 2009). At present, in Malaysia it is not difficult to find people with a mobile phone as the number of mobile phone subscribers is exceeding the number of the Malaysian population. It was reported that in 2011, the number of mobile phone services subscribers in Malaysia was 35, 700, 000 (Annual Report 2011, MCMC) whereas the number of Malaysian population was 29,062, 000 (Department of Statistics, Malaysia, 2013).

Consumer Complaint Behavior (CCB) is a topic that has received growing attention from the practitioners and the academicians for various reasons. No one manager in any industry will deny that a complaint from the customer gives an opportunity for the organization to improve. A complaint gives an organization a last chance to retain the customer if the organization reacts appropriately. On the other hand it is a legitimate and ethical act toward the consumer (Crié, 2003). As complaint gives benefits to the organization as well as to the consumer, $\mathrm{CCB}$ becomes a topic that is continuously being studied since in the 60 's. Although it started in the western countries, studies on CCB have been conducted in various continents of the world. Remarkably, studies on CCB 
are significant to various types of industries and sectors. The empirical evidence shows that studies on CCB were conducted in various industries, including manufacturing, automotive, services, electrical appliances and also in grocery (Broadbridge \& Marshall, 1995; Gronhaug, 1977; Landon, 1977).

To augment the literature on $\mathrm{CCB}$, this study was conducted in the mobile phone services in Malaysia. Mobile phone services were chosen based on the evidence that this industry has received high complaints rates as compared to other industries in Malaysia (The Star, 2013, November 28; 2012, April 9). In 2012, the Malaysian Communication and Multimedia Commission (MCMC) reported that a total of 757 complaints from various service providers were compiled. Interestingly, with not less than 35 million registered mobile phone subscribers the high number of complaints received is not compatible. This small percentage (3\%) of complaints conveys various connotations to various parties. On one hand, it is a good indicator to show that the services offered are excellent, on the other hand it hides unknown reasons.

Consumer complaining behavior is a significant issue crucial to the survival of any business (Kau \& Loh, 2006). The unknown problem of the organization if unresolved may affect its competitive advantage. That is the clear reason for CCB to receive growing attention in the service sector (Heung \& Lam, 2003; Ndubisi \& Ling, 2005; Snellman \& Vihtkari, 2003; Yuksel et al., 2006). As this issue is universal, this study attempts to investigate the scenario of CCB specifically in the mobile phone services industry in Malaysia and generally to the service sector. Significantly the result of the study will be able to confirm the constructs of CCB for future researchers. The findings will be useful to help better understand the processes consumers go through when they feel dissatisfied.

Empirical evidences have shown that various different constructs have been adopted in studying consumer complaint behavior (CCB). This study is conducted to identify the relevant constructs under CCB in the Malaysian mobile phone service based on the following research questions:

\section{a. What are the constructs of CCB?}

b. What is the internal consistency reliability of each construct under CCB?

c. Does CCB have good construct validity?

The objectives of the study are to identify the underlying constructs of CCB. Besides, the study also examined the internal consistency reliability as well as the validity of the constructs that can be used in studying CCB specifically in the Malaysian mobile phone services setting or in other services industries generally. The items and dimensions of CCB scale were developed and adapted based on the existing instruments that assessed the two dimensions of CCB namely public and private complaints.

\subsection{Literature Review}

At the early stage, studies on CCB were mainly to determine the determinants for complaining as well as developing the theoretical model of complaint behavior. Based on Hirschman's (1970) study, Day and Landon (1977) proposed a two-level hierarchical classification of actions due to the dissatisfaction which defines complaint behavior. They defined the action taken by the consumers as public action which involves seeking redress; taking legal action or third party complaint whereas the private action involves personal boycott and negative word-of-mouth to the relatives or friends. The take no-action consumers were described as forgetting about the incident and doing nothing. On the other hand, Warland, Herrmann and Willits (1975) found that consumers who got upset in the marketplace would take four options of actions. The upset consumers were most likely to complain personally to someone, do nothing, boycott the store or product or go through intermediaries. Jaccoby and Jaccard (1981) defined the action taken by an individual as communicating something negative regarding a product or service to either the company or to some third-party entity. Here in Malaysia, the third party entity may include the Consumer Associations that are available at each state, the National Consumers Complaints Centre (NCCC) or Communication and Multimedia Consumer Forum of Malaysia (CFM) designated by the MCMC, the government agency such as Ministry of Domestic Trade Co-operatives and Consumerism, political leaders and mass media.

The theory building research has evolved to further develop the CCB concept through empirical evidence such as Singh (1988) who come out with three categories of CCB; namely, voice (reflecting actions directed toward the seller), private (involving negative word-of-mouth and exit) and third party (relating actions directed towards external agencies and legal actions). Crié (2003) defined CCB as a process that constitutes a subset of all possible responses to perceived dissatisfaction around purchased episode, during consumption or during possession of the goods or services. This means that CCB is not an instant response, but a process, which does not directly depend on its initiating factors but on evaluation of the situation by the consumer and of its evolution 
over time. The many definitions and explanations make CCB unique and complex to the researchers in this field. The varying alternatives available has created some behaviors are incompatible and the others can be utilized by the consumers in various combinations (Day and Bodur, 1978). Customers can be loyal or exit, but if they choose exit, they cannot be loyal and vice versa whereas other options can be chosen altogether without any contradiction. A dissatisfied customer can choose to exit, engage in negative word-of-mouth, and complain to a third party showing a coherent behavior. Richins (1983) suggested that complaining activities involve three kinds of behaviors known as switching, making a complaint to the seller and telling the experience to others. Conversely, Huefner and Hunt (1994) simplified the conceptualizing of complaining behavior as four-dimensional phenomenon. In the earlier study, Hunt and Hunt (1990) incorporated retaliation, grudge-holding and avoidance as complaining behaviors in their own right. Based on this, Phau and Baird (2008) have conducted a study to see the effect of dissatisfaction and retaliation. Similarly, Singh and Pandya (1991) also considered $\mathrm{CCB}$ as four specific dimensions comprising exit action, negative word-of-mouth, voice action and third party action.

In later years, researchers on $\mathrm{CCB}$ were not strictly following the framework as suggested by the previous researchers who have come out with various definitions and views on CCB. Phau and Sari (2004) distinguished $\mathrm{CCB}$ into two main groups; complainers and non-complainers. Complainers are the consumers who take public and/or private actions and the non-complainers are the consumers that do not take action at all or only take private actions. They said that CCB is the entire responses triggered by perceived dissatisfaction, which is neither psychologically accepted nor quickly forgotten with consumption of a product or service. Heung and Lam (2003) defined CCB as a function of dissatisfaction, which is the result of negative and non-conforming purchase expectations. Volkov, Harker and Harker (2002) viewed CCB as a set of all behavioral and non-behavioral responses portrayed by consumers and $\mathrm{CCB}$ is influenced by many dimensions including situational variables, product type, personal variables and the intensity of the consumer's dissatisfaction. Crié (2003) sees CCB as two types of responses; behavioral and non-behavioral. The behavioral responses consist of public action and private action and the non-behavioral action is no action. Day and Landon's (1977) two-level of complaint behavior hierarchical classification (the first level distinguishes action from non-action and the second level distinguishes between private and public action) was employed by several researchers in later years (Ndubisi \& Ling, 2005; Matilla \& Wirtz, 2004). Tronvoll (2011) suggests that CCB is linked to negative and non-confirmation, which result in low price and performance expectations.

Perceptibly the literature implies $\mathrm{CCB}$ as a set of multiple responses that are triggered by perceived dissatisfaction towards the service provider/seller. It has been in agreement by previous researchers that the results of dissatisfaction include public action, private action and no action (Day \& Landon, 1977; Crié , 2003; Matilla \& Wirtz, 2004; Phau \& Sari, 2004; Ndubisi \& Ling, 2005), voice, private and third party (Singh, 1988), switching, making a complaint to the seller and telling the experience to others (Richin, 1983) and retaliation, grudge-holding and avoidance (Hunt \& Hunt, 1990). Unlike other concepts such as service quality, organizational commitment and many others, the literature also confirmed that there is no specific dimension for CCB. Nevertheless, this study adopts the taxonomy suggested by Crié (2003) as shown in Table 1.

Table 1. A taxonomy of the types of response to dissatisfaction (Crié, 2003)

\begin{tabular}{ccc}
\hline Response Type & \multicolumn{1}{c}{ Towards Entity } \\
\hline & $\begin{array}{c}\text { Public } \\
\text { (Sellers, manufacturers, official organizations, } \\
\text { associations, justice) } \\
\text { Complaint } \\
\text { Legal action } \\
\text { Return of the item } \\
\text { Request for repair } \\
\text { Non-behavioral }\end{array}$ & $\begin{array}{c}\text { Private } \\
\text { (Family, friends, relations) }\end{array}$ \\
& No action, with or without modification of the \\
attitude & Word of mouth \\
& Forget or forgive & \\
\hline
\end{tabular}

According to Crié (2003) the two types of responses due to dissatisfaction can be divided into two entities namely public and private for behavioral response. Under public action consumer may complaint, take legal action, return the item or request for repair to the sellers, manufacturers, service providers, official organizations 
and associations. Conversely entity under private may include family, friends and relations whereby the actions are word-of-mouth, boycott or leaving. As this study attempts to investigate the behavior of the consumers with regard to complaining, the non-behavioral response such as no action or do nothing is out of the focal point. Adding more definition to the actions, Heung and Lam (2003) defined public actions as seeking redress directly, seeking refund from the seller, complaining to the media, instigating legal actions and taking direct complaint actions to the firm or consumer agency. On the other hand, private actions refer to switching brands and firms, boycotting a firm's products, ceasing to patronize an establishment and negative word-of-mouth communications to friends and relatives (Broadbridge \& Marshall, 1995; Kim, Kim, Im, \& Shin, 2003; Tronvoll, 2011).

\section{Method}

\subsection{Population}

The population for the study is defined as all consumers of mobile phone services from all service providers namely Maxis Berhad (known as Maxis), DiGi Telecommunication Sdn. Bhd. (known as DiGi), Celcom Axiata Berhad (known as Celcom), and U-mobile in the state of Selangor, Wilayah Persekutuan Kuala Lumpur and Wilayah Persekutuan Putra Jaya. Selangor and Wilayah Persekutuan were chosen due to the total number of subscribers from these two states comprises of $28.6 \%(1,945,143)$ of the total subscribers in Malaysia. This will be able to produce a pool of respondents that can ensure the homogeneous characteristics. Besides, the respondents from these two states enable to represent respondents from other states in term of culture and values because the population in these states comes from various states in Malaysia.

\subsection{Procedures}

Self-administered questionnaires were used to gather the data due to the reason that a well-designed questionnaire provides high level of accuracy (Money, Samouel, \& Page, 2007). The study used mall-intercept method to select the respondents as it is impossible to obtain the sampling frame from service providers due to the confidentiality of consumers' details. Based on description by Ibrahim and $\mathrm{Ng}$ (2002), twelve shopping malls located in Selangor, Wilayah Persekutuan Kuala Lumpur and Wilayah Persekutuan Putrajaya were selected. The chosen shopping malls were Mid Valley, SOGO, Bukit Bintang Plaza and The Mines Sg Besi in Wilayah Persekutuan Kuala Lumpur. Only one shopping complex was selected in Wilayah Persekutuan Putrajaya that is The Alamanda. In Selangor Ampang Point, Selayang Mall, Subang Parade, SACC Mall Shah Alam, AEON Bukit Raja, Sunway Pyramid and Plaza Metro Kajang were selected. Besides the reasons mentioned above, the twelve shopping complexes were chosen based on the researcher's observation that all the selected shopping malls are visited by multiracial consumers which do not only reflect the typical people of Kuala Lumpur, Putrajaya and Selangor but also the general population of Malaysia. Thus, the representativeness of respondents to all major ethnic groups in Malaysia is ensured. Secondly, due to the accessibility reason, that is, easy access to these places either by researchers (and enumerators) and consumers. These places are actually located in strategic areas in Wilayah Persekutuan Kuala Lumpur, Putrajaya and Selangor in which consumers are provided with many transportation modes especially public transports such as commuter, LRT, monorail, buses and taxis. These transportation facilities could help the researcher and the team (enumerators) to easily get accessed to all the shopping malls to collect the data.

Table 2. Total of scale items used to measure CCB

\begin{tabular}{ccl}
\hline Constructs & Number of Items & \multicolumn{1}{c}{ Source } \\
\hline $\begin{array}{c}\text { Consumer Complaint Behavior } \\
\text { Public Action }\end{array}$ & 16 items: & \\
Private Action & 7 items & $\begin{array}{l}\text { Liu and McClure (2001); Ndubisi and Ling (2005); } \\
\text { Malhotra, Ndubisi and Agarwal (2008) } \\
\text { Liu and McClure (2001); Ndubisi and Ling (2005); } \\
\text { Malhotra et al. (2008) }\end{array}$ \\
\hline
\end{tabular}

\subsection{Measurement of $C C B$}

This study utilized a variety of validated scales to measure major constructs illustrated in the theoretical framework. Most of the validated scales were adapted to fit the sample of the research. In sum a total of 16 scale items were used to measure the constructs in this research. Table 2 lists the number and sources of the items used to measure each construct. 
The selection of the items was based on three criteria. First, the reliability of the item must have the Cronbach Alpha of 0.60 or greater. Second, the construct convergent and discriminant validity must meet the requirements. Finally, the theoretical guidance and judgment were used as the final selection of the items that best meet the domain of the specific construct as defined in the study. This study employed two latent constructs namely Public Action and Private Action for complainers whereas for non-complainers only one latent construct was suggested that is private action. In the questionnaire, respondents were asked whether they have made any complaint to the service provider/firm or any other third party agencies which are responsible to address consumers' complaints such as National Consumer Complaint Center (NCCC), Malaysian Communication and Multimedia Commission (MCMC), Communication and Multimedia Consumer Forum of Malaysia (CFM), consumer associations, political leaders or the mass media. Respondents who answered "YES" for this question were not allowed to response to statement number 1 to number 7 because these statements are meant for respondents who have lodged their frustration to the service provider/firm or any other third parties mentioned above.

The CCB scale was assessed with two subscales: public action and private action. All items were rated on a five-point Likert scale namely $1=$ strongly disagree and $5=$ strongly disagree. As this study focuses on the behavioral actions of the respondents, the opening of the statement is provided with a phrase "For the problem that I have encountered with my service provider, I always...." indicate that all responses must be based on the actual experiences. To reduce repetition, the phrase was placed on top of the list of the statements. The ratings within each scale are summed and divided by the total number of items in that particular scale in order to determine the score of the scale. The questionnaire was written in English and was translated back-to-back into Malay language by professional translators. It was re-checked by the researchers and the translators to ensure that the translation is correct before it can be used.

\subsection{Public Action}

Public Action is the action performed by consumers that involves the service provider or any other organizations that take care of consumers' complaints. In this case, the consumers dealt with the service provider or the organization to inform, discuss or request something with regard to their dissatisfaction. Items for this construct were taken from Liu and McClure (2001), Ndubisi and Ling (2006), and Malhotra et al. (2008). Seven items were used to measure soft public action on a five-point scale ranging from 1 (Strongly Disagree) to 5 (Strongly Agree). Respondents were asked to indicate their level of agreement on the given statements. Table 3 presents the seven original and modified items used in this study.

Table 3. Public action scale items

$$
\text { Original Scale Items }
$$

Modified Items

For the problem that I have encountered with my service provider, I always.....

\begin{tabular}{|c|c|c|}
\hline 1 & $\begin{array}{l}\text { I will discuss the problem with manager or other } \\
\text { employee of the bank. }\end{array}$ & $\begin{array}{l}\text { discuss the problem with manager or other } \\
\text { employee of the service provider. }\end{array}$ \\
\hline 2 & $\begin{array}{l}\text { I will ask the bank to take care of the problem (e.g. } \\
\text { to fix, replace item or to do better in the future). }\end{array}$ & $\begin{array}{l}\text { request the service provider to take care of the } \\
\text { problem (e.g. to fix, replace item or to do better in } \\
\text { the future). }\end{array}$ \\
\hline 3 & $\begin{array}{l}\text { I will inform the bank about the problem so that } \\
\text { they will able to do better in the future. }\end{array}$ & $\begin{array}{l}\text { inform the service provider for improvement in } \\
\text { future. }\end{array}$ \\
\hline 4 & $\begin{array}{l}\text { I will write a letter to the local newspaper or mass } \\
\text { media about my bad experience. }\end{array}$ & write a letter to a local newspaper or mass media. \\
\hline 5 & I will report the problem to a consumer agency. & report the problem to a consumer agency. \\
\hline 6 & $\begin{array}{l}\text { I will complain to the government agency or } \\
\text { politician. }\end{array}$ & complain to a government agency or politician. \\
\hline 7 & I will take legal action against the bank. & take legal action against the service provider. \\
\hline
\end{tabular}

\subsection{Private Action}

The second construct, private action refers to the action taken by the consumers that does not involve the service 
provider directly. In other words, consumers do not complain the matter to the service provider or to any relevant authority. However, consumers tell their friends or relative regarding their dissatisfaction. Consumers also sometime convince their friends or relative not to use the services of the service provider again. Respondents were asked to indicate their agreement on the given statements. Nine items were used to measure private action on a five-point scale ranging from 1 (Strongly Disagree) to 5 (Strongly Agree). Similarly, the opening phrase "For the problem that I have encountered with my service provider, I always...." is also provided to indicate that all responses must be based on the actual experiences. Table 4 below illustrates the seven items measurement including the modified items.

Table 4. Private action scale items

Original Scale Items
Modified Items

For the problem that I have encountered with my service provider, I always.....

1 I will speak to my friends about my bad experience.

2 I will tell my relatives never to use the service again.

3 I will convince my friends not to do business with the bank.

4 convince my relatives not to do business with the service provider.

5 tell my friends never to use this service provider's service again.

6 tell my relatives never to use this service provider's services again.

7 write on my internet social interactive mediums accounts to tell others about my bad experience with this service provider.

8 I will decide never to use the service again.

9 I will patronize another bank next time. speak to my friends about my bad experience with the service provider.

speak to my relatives about my bad experience with the service provider.

convince my friends not to do business with the service provider.

convince my relatives not to do business with the service provider.

tell my friends never to use this service provider's service again.

tell my relatives never to use this service provider's services again.

write on my internet social interactive mediums accounts to tell others about my bad experience with this service provider.

Use this service provider when I absolutely have to. decided to use other service provider next time.

\section{Results}

\subsection{Data Analisis}

In this study, the Statistical Package for Social Sciences (SPSS) version 21 was used to analyze the quantitative data gathered via the use of questionnaire. The screening process was carried out to identify the missing data, to assign code, to identify outliers and to check the normality as well as to analyze the frequencies, mean and standard deviation. These analyses were conducted for each of the variables to gain preliminary information about the sample. This information gives the reader a 'snapshot' of the data collected and used in the research. SPSS was also used to conduct the exploratory factor analysis (EFA) in order to identify the underlying factors of CCB. According to Child, (1990) traditionally EFA has been used to explore the possible underlying factor structure of a set of observed variables without imposing a preconceived structure on the outcome. The data from the pilot study were used to check the reliability of the items as well as to identify the underlying factors of the constructs. SPSS version 21 was used to run the reliability test and analyze the constructs. A total of 100 questionnaires from the complainers and 105 from the non-complainers were used for the purpose (Kline, 1979; Gorsuch, 1983; Furguson \& Cox, 1993).

Amos version 21 was then used to conduct the confirmatory factor analysis (CFA). CFA is a statistical technique used to verify the factor structure of a set of observed variables. CFA allows a researcher to test the hypothesis regarding a relationship between observed variables and their underlying latent construct. CFA is also employed to explore statistical relationships among the items of each factor as well as to verify the unidimensionality of the latent construct in the first step. Hair, Black, Babin, Anderson and Tatham (2006) define unidimensionality as an assumption underlying the calculation of reliability and is demonstrated when the indicators of a construct has an acceptable fit on a single-factor (one-dimensional) model. The unidimensional measurement models are more 
useful because they offer more precise tests of convergent and discriminate validity of factor measurement (Anderson \& Gerbing, 1988). The first step is therefore to ensure that a set of items empirically measures a single dimension. This study has conducted the unidimensionality assessment prior to testing the reliability and validity of each construct as suggested by Anderson and Gerbing (1982); Dunn, Seaker and Waller (1994) and Hair et al. (2006).

\subsection{Preliminary Analysis}

The preliminary analysis is based on the pilot test. A total number of 100 questionnaires for complainers and 105 non-complainers were collected from groups of post-graduate students and academic staff of Universiti Teknologi MARA, Puncak Alam campus. The results of the reliability tests shown in Table 5 fulfilled the requirement as suggested by Hair et al. (2010).

Table 5. Summary Statistics for CCB and Cronbach's Alpha

\begin{tabular}{lcccc}
\hline \multicolumn{1}{c}{ CCB } & N & \# of items & Mean & $\boldsymbol{\alpha}$ \\
\hline Complainer & 100 & 7 & & \\
Public Action & & 9 & 3.74 & .66 \\
Private Action & & 16 & 2.18 & .91 \\
$\quad \begin{array}{l}\text { Overall Complainer } \\
\text { Non-complainer }\end{array} \quad$ & & & .86 \\
Private Action & 105 & 9 & 3.07 & .86 \\
\hline
\end{tabular}

Table 6. Factor Loadings for CCB (Complainer)

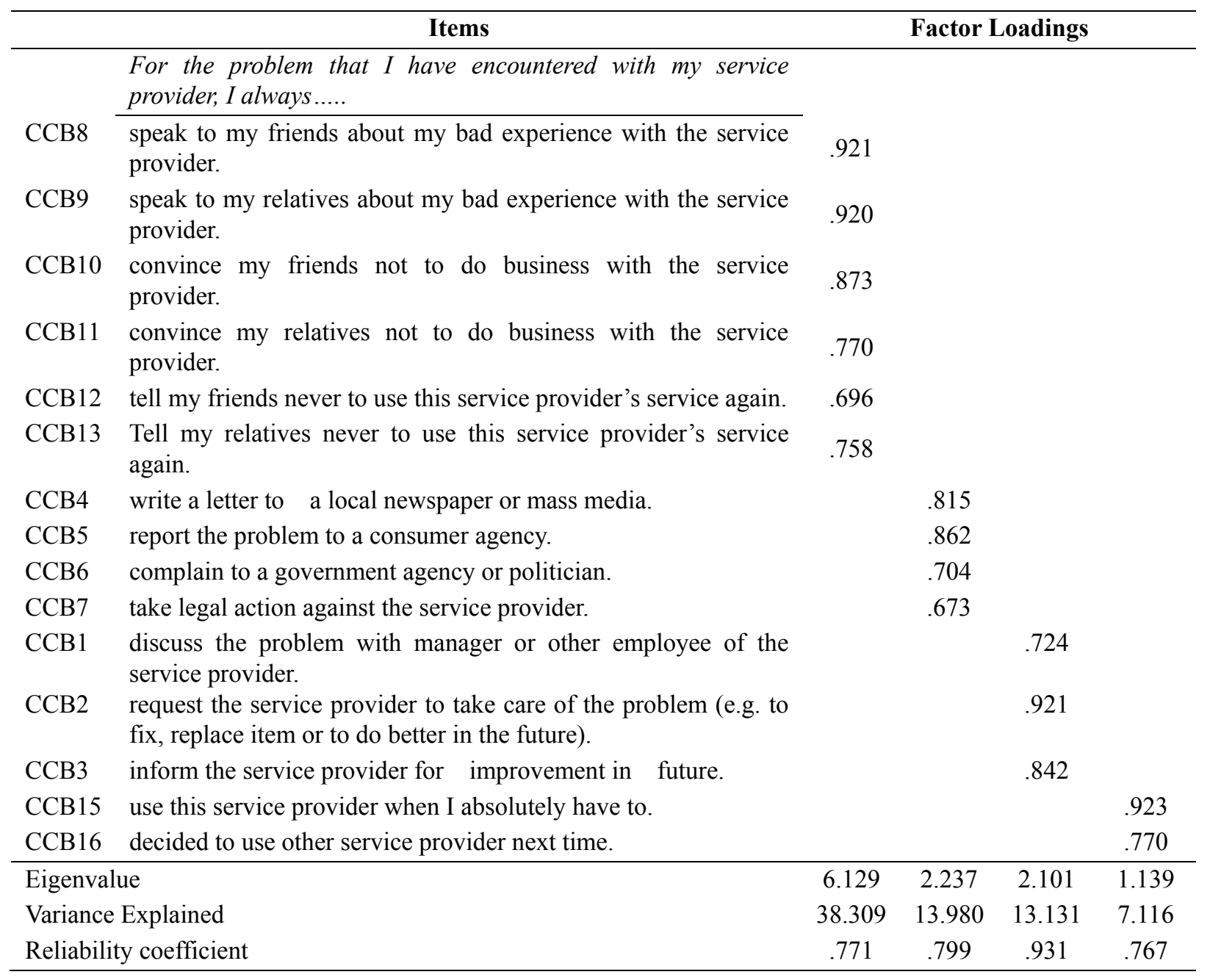


The results of factor analysis show that there are four factors of CCB for complainers and three factors for non-complainers. For complainers, the results explain that items for public actions fall under two separate factors and items for private actions also fall under two separate factors. The first factor consist of items CCB8, CCB9, CCB10, CCB11, CCB12 and CCB13, items CCB4, CCB5, CCB6 and CCB7 the second factor, items CCB1, CCB2 and CCB3 the third factor and items CCB15 and CCB16 is the fourth factor. The results have clearly indicated that public actions are divided into two categories and two categories for private actions as well.

Looking at the items (CCB4, CCB5, CCB6 and CCB7), this group can be categorized as "Extreme Public Action" and another group (items CCB1, CCB2 and CCB3) can be categorized as "Soft Public Action." The reason for naming the group is based on the keywords used in the items such as "discuss," "request," and "inform" for Soft Public Complaint and "write," "report," "complain," and "take legal action" which is more stern. In previous studies, using items CCB1, CCB2 and CCB3 for public action Liu, Watkins and Youjae (1997), Singh (1988), Liu and McClure (2001) named it as "Voice Responses" whereas items CCB4, CCB5, CCB6 and CCB7 as third party responses. On the other hand, Ndubisi and Ling (2006), Malhotra et al. (2008) and Kitapci and Dortyol (2009) lumped all items into public complaint. Since there is inconsistency of using the items, we decided to name the two categories of public actions as Soft Public Action and Extreme Public Action.

As for private action, the results also show the existence of two categories. The first category consists of items CCB8, CCB9, CCB10, CCB11, CCB12 and CCB13 while the second category consists of items CCB15 and CCB16. Using the same method as in Public Action, we looked at the key words used in items for the first category and second category. The key words for items in the first category are "speak," "tell," and "convince" friends or relatives but the key words for items in the second category are "use when have to," and "use other service provider." The first category gives us the idea that the consumers may not leave the service provider because consumers only speak, tell and convince their friends or relatives. However, the second category is clearly indicated that the consumers are hardheartedly wanted to leave the service provider.

In previous studies Liu et al. (1997), Singh (1988) and Liu and McClure, (2001) categorized items that used the keywords "speak," "convince," "avoided" and "buy from another firm" as private responses. On the other hand, Malhotra et al. (2008), Kitapci and Dortyol (2009) segregated them into "private complaint" and "defection". This inconsistency leaves us the choice to choose the names for the two categories. Although all actions are done without involving the service provider or a third party, actions like "use when have to" and "use other service provider" are considered as stern action and therefore we named it as Extreme Public Action and Soft Private Action for another category. Table 6 and 7 explain the results of the factor analysis.

Table 7. Factor Loadings for CCB (Non-Complainer)

$$
\text { Items }
$$

Factor Loadings

\begin{tabular}{|c|c|c|c|}
\hline & $\begin{array}{l}\text { For the problem that I have encountered with my service provider, I } \\
\text { always..... }\end{array}$ & & \\
\hline CCB8 & speak to my friends about my bad experience with the service provider. & .808 & \\
\hline CCB9 & speak to my relatives about my bad experience with the service provider. & .781 & \\
\hline $\mathrm{CCB} 10$ & convince my friends not to do business with the service provider. & .910 & \\
\hline CCB11 & convince my relatives not to do business with the service provider. & .862 & \\
\hline $\mathrm{CCB} 12$ & tell my friends never to use this service provider's service again. & .732 & \\
\hline $\mathrm{CCB} 13$ & tell my relatives never to use this service provider's services again. & .697 & \\
\hline CCB14 & $\begin{array}{l}\text { write on my internet social interactive mediums accounts to tell others about my } \\
\text { bad experience with this service provider. }\end{array}$ & & .428 \\
\hline $\mathrm{CCB} 15$ & use this service provider when I absolutely have to. & & .855 \\
\hline CCB16 & decided to use other service provider next time. & & .895 \\
\hline \multicolumn{2}{|c|}{ Eigenvalues } & 4.638 & 1.268 \\
\hline \multicolumn{2}{|c|}{ Variance Explained } & 51.400 & 13.843 \\
\hline \multicolumn{2}{|c|}{ Reliability coefficient } & .906 & .775 \\
\hline
\end{tabular}




\subsection{Confirmatory Factor Analysis}

Worthington and Whittaker (2006) in their study of scale development mentioned that researchers typically use CFA after an instrument has already been assessed using EFA in order to know if the factor structure produced by EFA fits the data from a new sample. In this study, a usable data of 230 complainers and 280 non-complainers of mobile phone users were used to conduct the CFA. The standardized estimates are reported to interpret parameters in the measurement model. Table 8 shows the fit indices tested for complainers and non-complainers and the results indicate good fit for all indices.

Table 8. Fit Indices and the result for complainers and non-complainers

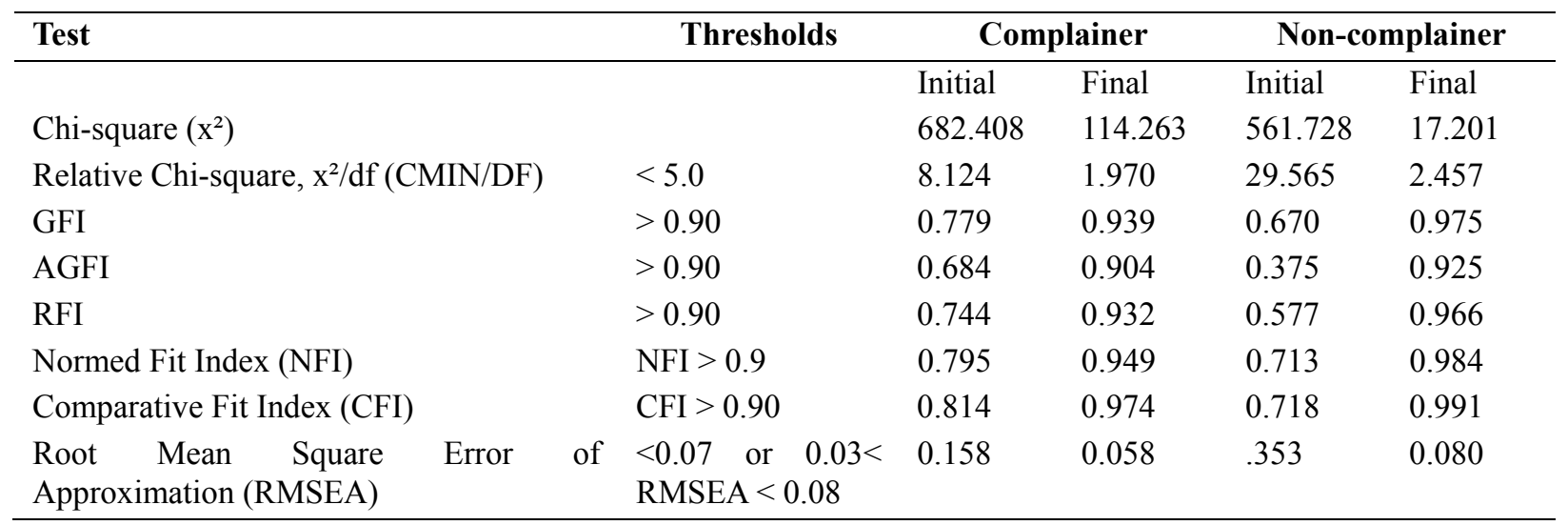

Table 9. The result of construct reliability, average variance extracted and Cronbach's Alpha

\begin{tabular}{|c|c|c|c|c|c|}
\hline Construct & Items & $\begin{array}{l}\text { Standardized } \\
\text { Loadings }\end{array}$ & $\begin{array}{l}\text { Construct } \\
\text { Reliability }\end{array}$ & $\begin{array}{l}\text { Average Variance } \\
\text { Extracted }\end{array}$ & $\alpha$ \\
\hline \multicolumn{6}{|l|}{ Complainer } \\
\hline \multirow[t]{3}{*}{ Soft Public Action } & CCB1 & 0.63 & 0.72 & 0.59 & 0.810 \\
\hline & $\mathrm{CCB} 2$ & 0.75 & & & \\
\hline & $\mathrm{CCB} 3$ & 0.90 & & & \\
\hline \multirow[t]{4}{*}{ Extreme Public Action } & CCB4 & 0.83 & 0.73 & 0.55 & 0.821 \\
\hline & CCB5 & 0.68 & & & \\
\hline & CCB6 & 0.73 & & & \\
\hline & CCB7 & 0.72 & & & \\
\hline \multirow[t]{4}{*}{ Soft Private Action } & CCB9 & 0.63 & 0.89 & 0.74 & 0.918 \\
\hline & $\mathrm{CCB} 10$ & 0.83 & & & \\
\hline & $\mathrm{CCB} 12$ & 0.96 & & & \\
\hline & $\mathrm{CCB} 13$ & 0.98 & & & \\
\hline \multirow[t]{2}{*}{ Extreme Private Action } & $\mathrm{CCB} 15$ & 0.82 & 0.67 & 0.62 & 0.762 \\
\hline & $\mathrm{CCB} 16$ & 0.75 & & & \\
\hline \multicolumn{6}{|l|}{ Non-Complainer } \\
\hline \multirow[t]{4}{*}{ Soft Private Action } & CCB9 & 0.60 & 0.88 & 0.84 & 0.911 \\
\hline & CCB10 & 0.79 & & & \\
\hline & $\mathrm{CCB} 12$ & 0.98 & & & \\
\hline & $\mathrm{CCB} 13$ & 0.97 & & & \\
\hline \multirow[t]{2}{*}{ Extreme Private Action } & $\mathrm{CCB} 15$ & 0.75 & 0.67 & 0.62 & 0.761 \\
\hline & CCB16 & 0.82 & & & \\
\hline
\end{tabular}

\subsection{Validity of the Constructs}

The validity of the constructs has met the requirement of average variance extracted (AVE), construct reliability, convergent validity and discriminant validity. In order to further confirm on the reliability of the construct, the 
average variance extracted (AVE) and construct reliability (CR) are calculated based on the formulas by Fornell and Larcker (1981).

Accordingly, construct validity is confirmed based on goodness-fit-indices (Hsieh and Hiang, 2004) reported in the earlier section. Evidence of convergent validity is found based on high factor loadings (greater than 0.50) of all factors (Anderson and Gerbing 1988; Cunningham, Holmes-Smith and Coote, 2006). In addition, the results of AVE provide further support for convergent validity. In the case of discriminant validity, the correlations between factors in the measurement model do not exceed 0.85 as recommended by Kline (2005). Table 9 shows the result of construct validity for complainer and non-complainer.

\section{Conclusion}

Due to different definitions and underlying dimensions of $\mathrm{CCB}$, this paper is intended to provide an empirically validated construct of $\mathrm{CCB}$ that can be used by those interested in this matter. The findings provide the empirical evidence that there are four underlying factors of $\mathrm{CCB}$ for complainers and two factors for non-complainers. The main factors for complainers are public action and private action. However, the results of EFA show that public and private actions are divided into two categories. Since there is inconsistency with regard to the names of the factors based on the previous studies, reference has been made to the highest loadings and the factors have been named as soft public action, extreme public action, soft private action and extreme private action. The result of CFA confirmed that these factors to be the underlying dimensions of CCB for complainers. On the other hand, since the non-complainers do not involve in complaining directly to the service provider or firm, this type of consumers are left with one choice of CCB that is private action.

The results of EFA also suggest that private actions for non-complainers to be divided into two groups. Similar to the complainers, we named the categories as soft private action and extreme private action since there is no difference of items used. The CFA results also confirm these two factors as the dimensions of CCB for non-complainers. The coefficient alphas that exceed 0.60 for all factors in exploratory factor analysis support the factorial validity of the CCB scale. Such findings suggest acceptable reliability and validity of the instrument. The results of confirmatory factor analysis provided the evidence of construct validity based on the tests of significance and assessment of the measurement model fit. Consequently, the subscales can be regarded as useful instruments in examining the CCB construct in Malaysian setting. The instrument can be used by Malaysian researchers in assessing CCB as all of the items measure what they are supposed to measure.

\section{References}

Anderson, J. C., \& Gerbing, D. W. (1988). Structural equation modeling in practice: A review and recommended two-step approach. Psychological Bulletin, 103(3), 411. http://dx.doi.org/10.1037/0033-2909.103.3.411

Broadbridge, A., \& Marshall, J. (1995). Consumer complaint behavior: the case of electrical goods. International Journal of Retail \& Distribution Management, 23(9), 8-18. http://dx.doi.org/10.1108/09590559510098663

Crie, D. (2003). Consumers' complaint behavior. Taxonomy, typology and determinants: towards a unified ontology. The Journal of Database Marketing \& Customer Strategy Management, 11(1), 60-79. http://dx.doi.org/10.1057/palgrave.dbm.3240206

Cunningham, E., Holmes-Smith, P., \& Coote, L. (2006). Structural equation modeling: From the fundamentals to advanced topics. Melbourne, AU: Streams Statsline.

Day, R. L., \& Bodur, M. (1978). Consumer response to dissatisfaction with services and intangibles. Advances in Consumer Research, 5(1), 263-272. Retrieved from http://www.acrwebsite.org/search/view-conferenceproceedings.aspx? $\mathrm{Id}=9433$

Day, R. L., \& Landon, E. L. (1977). Toward a theory of consumer complaining behavior. Consumer and Industrial Buying Behavior, 95, 425-437.

Department of Statistics, Malaysia. (2013). Population Quick Info. Retrieved from http://www.statistics.gov. $\mathrm{my} /$ portal/index.php?option=com_content\&view $=$ article\&id $=471 \&$ lang $=$ en\&Itemid $=0$

Dunn, S. C., Seaker, R. F., \& Waller, M. A. (1994). Latent variables in business logistics research: scale development and validation. Journal of Business Logistics, 15, 145-145. Retrieved from http://gkwl.nbu.edu.cn/4pl/gwxsrw/11.pdf

Ferguson, E. \& Cox, T. (1993). Exploratory factor analysis: a user's guide. International Journal of Selection and Assessment, 1, 84-94. http://dx.doi.org/10.1111/j.1468-2389.1993.tb00092.x

Fornell, C., \& Larcker, D. F. (1981). Structural equation models with unobservable variables and measurement 
error: Algebra and statistics. Journal of Marketing Research, 382-388. http://www.jstor.org/stable/3151312

Gorsuch, R. L. (1983). Factor analysis (2nd ed.). New York: McGraw-Hill.

Gronhaug, K. (1977). Exploring consumer complaining behavior: A model and some empirical results. Advances in Consumer Research, 4(1), 159-165. http://dx.doi.org/10.1016/0167-4870(81)90034-9

Hair, J. F. Jr., Black, W. C., Babin, B. J., Anderson, R. E., \& Tatham, R. L. (2006). Multivariate Data Analysis. Upper-Saddle River, New Jersey: Prentice Hall.

Heung, V. C., \& Lam, T. (2003). Customer complaint behavior towards hotel restaurant services. International Journal of Contemporary Hospitality Management, 15(5), 283-289. http://dx.doi.org/10.1108/095961103 10482209

Hirschman, A. O. (1970). Exit, voice, and loyalty: Responses to decline in firms, organizations, and states (Vol. 25). Harvard university press.

Hsieh, Y. C., \& Hiang, S. T. (2004). A study of the impacts of service quality on relationship quality in search-experience-credence services. Total Quality Management \& Business Excellence, 15(1), 43-58. http://dx.doi.org/10.1080/1478336032000149090

http://www.thestar.com.my/Business/Business-News/2013/11/28/3g-services-under-mcmc-scrutiny/

http://www.thestar.com.my/News/Nation/2012/04/09/MCMC-Telco-asked-to-find-a-way-to-stop-unwanted-SM/

Huefner, J. C., \& Hunt, H. K. (1994). Extending the Hirschman model: when voice and exit don't tell the whole story. Journal of Consumer Satisfaction, Dissatisfaction and Complaining Behavior, 7(1), 267-270. Retrieved from http://lilt.ilstu.edu/staylor/csdcb/articles/Volume7/Huefner\%20et\%20al\%201994.pdf

Hunt, D. H., \& Hunt, K. H. (1990). Customer grudgeholding: Further conceptualization and analysis. Journal of Consumer Satisfaction, Dissatisfaction and Complaining Behavior, 3, 117-122. Retrieved from http://lilt.ilstu.edu/staylor/csdcb/articles/Volume3/Hunt\%20et\%20al\%201990.pdf

Ibrahim, M. F., \& Ng, C. W. (2002). Determinants of entertaining shopping experiences and their link to consumer behavior: case studies of shopping centers in Singapore. Journal of Retail \& Leisure Property, 2(4), 338-357. http://dx.doi.org/10.1057/palgrave.rlp.5090155

Jacoby, J., \& Jaccard, J. J. (1981). The sources, meaning, and validity of consumer complaint behavior: A psychological analysis. Journal of Retailing, 57(3), 4-24. http://psycnet.apa.org/psycinfo/1984-10992-001

Kau, A. K., \& Loh, E. W. Y. (2006). The effects of service recovery on consumer satisfaction: a comparison between complainants and non-complainants. Journal of Services Marketing, 20(2), 101-111. http://dx.doi.org/10.1108/08876040610657039

Kim, C., Kim, S., Im, S., \& Shin, C. (2003). The effect of attitude and perception on consumer complaint intentions. Journal of Consumer Marketing, 20(4), 352-371. http://dx.doi.org/10.1108/07363760310483702

Kitapci, O., \& Dortyol, I. T. (2009). The differences in customer complaint behavior between loyal customers and first comers in the retail banking industry: The case of Turkish customers. Management Research News, 32(10), 932-941. http://dx.doi.org/10.1108/01409170910994141

Kline, P. (1979). Psychometric and psychology. London: Academic Press.

Kline, R. B. (2005). Principles and Practice of Structural Equation Modeling (2nd ed.). New York: The Guilford Press.

Landon, E. L. (1977). A model of consumer complaint behavior. Journal of Consumer Satisfaction, Dissatisfaction and Complaining Behavior, 31-35.

Liu, R. R., \& McClure, P. (2001). Recognizing cross-cultural differences in consumer complaint behavior and intentions: an empirical examination. Journal of Consumer Marketing, 18(1), 54-75. http://dx.doi.org/10. $1108 / 07363760110365813$

Liu, R. R., Watkins, H. S., \& Yi, Y. (1997). Taxonomy of consumer complaint behavior: replication and extension. Journal of Consumer Satisfaction, Dissatisfaction and Complaining Behavior, 10, 91-103. Retrieved from http://ilt.ilstu.edu/staylor/csdcb/articles/Volume10/Liu\%20et\%20al\%201997.pdf

Malaysian Communication and Multimedia Commission. (2011). Annual Report 2011. Retrieved from http://www.skmm.gov.my/skmmgovmy/media/General/pdf/SKMM_11eng.pdf

Malhotra, N. K., Oly-Ndubisi, N., \& Agarwal, J. (2008). Public versus private complaint behavior and customer 
defection in Malaysia, appraising the role of moderating factors. EsicMarket, (September-December), 27-59. Retrieved from http://www.esic.edu/documentos/revistas/esicmk/080912_104135_I.pdf

Mattila, A. S., \& Wirtz, J. (2004). Consumer complaining to firms: the determinants of channel choice. Journal of Services Marketing, 18(2), 147-155. http://dx.doi.org/10.1108/08876040410528746

Money, A. H., Samouel, P., \& Page, M. (2007). Research methods for business (pp. 210-425). Chichester, England: John Wiley \& Sons.

Ndubisi, N. O., \& Ling, T. Y. (2006). Complaint behavior of Malaysian consumers. Management Research News, 29(1), 65-76. http://dx.doi.org/10.1108/01409170610645457

Phau, I., \& Baird, M. (2008). Complainers versus non-complainers retaliatory responses towards service dissatisfactions. Marketing Intelligence \& Planning, 26(6), 587-604. http://dx.doi.org/10.1108/0263450081 0902848

Phau, I., \& Sari, R. P. (2004). Engaging in complaint behavior: an Indonesian perspective. Marketing Intelligence \& Planning, 22(4), 407-426. http://dx.doi.org/10.1108/02634500410542770

Richins, M. L. (1983). Negative word-of-mouth by dissatisfied consumers: a pilot study. The Journal of Marketing, 68-78. Retrieved from http://www.jstor.org/stable/3203428

Schumacker, R. E., \& Lomax, R. G. (2004). A beginner's guide to structural equation modeling. Mahwah, NJ: Lawrence Erlbaum Associates.

Singh, J. (1988). Consumer complaint intentions and behavior: definitional and taxonomical issues. The Journal of Marketing, 93-107. Retrieved from http://www.jstor.org/stable/1251688

Singh, J., \& Pandya, S. (1991). Exploring the effects of consumers' dissatisfaction level on complaint behaviors. European Journal of Marketing, 25(9), 7-21. http://dx.doi.org/10.1108/EUM0000000000621

Snellman, K., \& Vihtkari, T. (2003). Customer complaining behavior in technology-based service encounters. International Journal of Service Industry Management, 14(2), 217-231. http://dx.doi.org/10.1108/ 09564230310474174

Tronvoll, B. (2011). Negative emotions and their effect on customer complaint behavior. Journal of Service Management, 22(1), 111-134. http://dx.doi.org/10.1108/09564231111106947

Volkov, M., Harker, D., \& Harker, M. (2002). Complaint behavior: a study of the differences between complainants about advertising in Australia and the population at large. Journal of Consumer Marketing, 19(4), 319-332. http://dx.doi.org/10.1108/07363760210433636

Warland, R. H., Herrmann, R. O., \& Willits, J. (1975). Dissatisfied consumers: Who gets upset and who takes action. Journal of Consumer Affairs, 9(2), 148-163. http://dx.doi.org/10.1111/j.1745-6606.1975.tb00559.x

Worthington, R. L., \& Whittaker, T. A. (2006). Scale development research: a content analysis and recommendations for best practices. The Counseling Psychologist, 34, 806-834. http://dx.doi.org/10.1177/0011000006288127

Yang, H. J., \& Lay, Y. L. (2011). Factors Affecting College Student's Mobile Phone Dependence and Anxiety. In Proceedings of the World Congress on Engineering and Computer Science (Vol. 2). Retrieved from http://www.iaeng.org/publication/WCECS2011/WCECS2011_pp1117-1120.pdf

Yuksel, A., Kilinc, U., \& Yuksel, F. (2006). Cross-national analysis of hotel customers' attitudes toward complaining and their complaining behaviors. Tourism Management, 27(1), 11-24. http://dx.doi.org/10.1016/j.tourman.2004.07.007

Zulkefly, S. N., \& Baharudin, R. (2009). Mobile phone use amongst students in a university in Malaysia: its correlates and relationship to psychological health. European Journal of Scientific Research, 37(2), 206-218. Retrieved from http://www.eurojournals.com/ejsr.htm

\section{Copyrights}

Copyright for this article is retained by the author (s), with first publication rights granted to the journal.

This is an open-access article distributed under the terms and conditions of the Creative Commons Attribution license (http://creativecommons.org/licenses/by/3.0/). 